\title{
HUBUNGAN KERAPATAN PENDUDUK DENGAN KEANEKARAGAMAN TANAMAN BUAH PEKARANGAN DI KECAMATAN GODEAN, KABUPATEN SLEMAN, YOGYAKARTA \\ (Relationship between Population Density and Diversity of Yard Fruit Plants in Godean Sub-District, Sleman District, Yogyakarta)
}

\author{
Fransisca Kiki Fajarwati*, Suwarno Hadisusanto, dan Hartono \\ Sekolah Pascasarjana, Universitas Gadjah Mada, \\ Jl. Teknika Utara, Pogung Kidul, Sinduadi, Mlati, Sleman, Yogyakarta 55281.
}

*Penulis korespondensi. Tel: 085725663436. Email: fransiscakikifajarwati@gmail.com.

Diterima: 14 Januari 2020

Disetujui: 9 Maret 2020

\begin{abstract}
Abstrak
Tanaman buah sangat besar manfaatnya bagi manusia dan lingkungan hidup antara lain berperan untuk menjaga kawasan hijau di kawasan hunian, namun keberadaannya di pekarangan saat ini teracam karena meningkatnya alih fungsi lahan dari pekarangan menjadi lahan terbangun untuk tempat tinggal seiring dengan pertambahan jumlah manusia. Tujuan penelitian ini adalah menganalisis persebaran kerapatan penduduk, keanekaragaman tanaman buah, hubungan kerapatan penduduk dengan keanekaragaman tanaman buah, adaptasi masyarakat dalam melestarikan tanaman buah dan pekarangan dan menyusun usulan pelestarian tanaman buah dan pekarangan di Kecamatan Godean, Kabupaten Sleman. Metode yang digunakan adalah observasi dan memanfaatkan data sekunder dengan periode waktu penelitian selama sepuluh bulan. Hasil yang diperoleh adalah kerapatan penduduk di Kecamatan Godean semakin ke bagian timur (mendekati Kota Yogyakarta) memiliki angka semakin tinggi. Semakin rapat penduduk maka semakin rendah indeks keanekaragaman dan kemerataan, semakin tinggi indeks dominansi, semakin sedikit jumlah jenis tanaman buah yang ditemukan, dan semakin sedikit kawasan hijau di kawasan hunian. Lokasi dengan kerapatan penduduk semakin tinggi terjadi adaptasi pelestarian tanaman buah dan pekarangan yang mendukung konsep lanskap produktif. Usulan pelestarian tanaman buah dan pekarangan disusun dengan mempertahankan usaha pemerintah dan warga yang dirasa efektif, memperbaiki atau menghilangkan yang kurang efektif dan menyusun usulan baru dengan harapan agar tetap dapat menjaga lingkungan hidup dengan menjaga kawasan hijau di kawasan hunian berdasarkan permasalahan yang ditemukan di lapangan.
\end{abstract}

Kata kunci: alih fungsi lahan, kawasan hijau, kawasan hunian, konsep lanskap produktif, lingkungan hidup.

\begin{abstract}
Fruit plants are very beneficial for human and environment, including their role is protecting green areas in residential areas, but their presence in the yard today is threatened because the increasing conversion of land functions from yard to building for shelter along with the increase in the number of people. The purpose of this study is to analyze the distribution of population density, the relationship between population density and diversity of fruit plants, community adaptation to conserve fruit plants and yard, and to give the recommendation for fruit plants and yard conservation in Godean Sub-District, Sleman District. The methods used are observation and utilizing secondary data with a research period of ten months. The study found that the population density in eastern part of Godean District (approaching the City of Yogyakarta) had higher numbers. The higher population density is, the lower diversity and evenness index, the higher the dominance index, the fewer the number of fruit plants found, and the less green areas in residential areas. Locations with higher population densities are adapted to conserve the fruit plants and yard. These findings support the concept of productive landscapes. Recommendation for fruit plants and yard conservation was compiled by maintaining goverment and citizen efforts that are felt to be effective, repairing or eliminating ones that are less effective and making new recommendation with the hope that it can protect the environment by protecting green areas in residential areas based on problems found in the field.
\end{abstract}

Keywords: land use change, green areas, residential area, productive landscape concepts, environment.

\section{PENDAHULUAN}

Tanaman buah sangat besar manfaatnya bagi manusia dan lingkungan hidup antara lain berperan untuk menjaga kawasan hijau di kawasan hunian. Berdasarkan fungsinya bagi lingkungan, pohon buah yang memiliki ukuran batang besar dapat memperbaiki iklim mikro, penyerap polusi udara, pereduksi kebisingan, mengurangi bahaya erosi, serta memberikan naungan kepada manusia, binatang, dan tanaman-tanaman disebelahnya (Dwipa dan Priyanti, 2016; Priyanti dan Fauziah, 
2016). Menurut Ali (2016), berdasarkan hasil penelitiannya diketahui lima daun vegetasi dengan daya serap $\mathrm{CO}_{2}$ terbesar, empat di antaranya adalah pohon buah yakni pohon matoa, nangka, jambu air, dan belimbing. Hasil lain adalah lima batang vegetasi dengan daya serap $\mathrm{CO}_{2}$ terbesar, empat di antaranya juga merupakan pohon buah yakni pohon kedondong, talok, nangka, dan jambu air.

Manfaat lain tanaman buah adalah buahnya dapat dikonsumsi bahkan dijadikan sumber pangan seperti yang terjadi di daerah urban. Tanaman buah dijadikan obat/ berguna bagi kesehatan, tanaman hias, kulit buah atau serabut sebagai sumber tanin atau pewarna, bunga untuk wewangian (jeruk), buah untuk diekstraksi minyaknya (alpukat) atau untuk disadap papainnya (pepaya), batang dimanfaatkan untuk kayu, dan sebagai sumber ekonomi (Ajesh dkk, 2012; Brahma dkk, 2013; Priyanti dan Fauziah, 2016; Navia dkk, 2017). Akan tetapi keberadaan tanaman buah di pekarangan saat ini teracam seiring dengan pertambahan jumlah populasi manusia. Kota semakin berkembang, mengalami urbanisasi yang akhirnya merambah ke wilayah pedesaan dan ruang-ruang terbuka menjadi menghilang. Lahan alami berubah menjadi lahan terbangun dan menghilangkan sejumlah vegetasi. Ekosistem ikut berubah, sejumlah pohon yang merupakan potensi keanekaragaman hayati sebagai penghasil $\mathrm{O}_{2}$ dan penyerap $\mathrm{CO}_{2}$ hilang berganti dengan bangunan yang justru menambah produksi $\mathrm{CO}_{2}$ (Ali, 2016).

Lokasi penelitian terletak di Kecamatan Godean, wilayah pinggiran kota Kota Yogyakarta. Kota Yogyakarta sebagai pusat kota berpotensi menciptakan dan meningkatkan skala urbanisasi DIY. Konsenkuensi peningkatan skala urbanisasi tersebut adalah kecenderungan terjadinya pencarian dan perpindahan tempat permukiman ke daerah pinggiran kota sehingga menyebabkan tumbuh berkembang pembangunan fisik di daerah permukiman baru. Selama 5 tahun terakhir dari tahun 2012 hingga 2017, konversi lahan di Kecamatan Godean relatif tinggi. Lahan sawah berkurang seluas 217 ha, lahan pekarangan berkurang seluas 128,48 ha, dan lahan bukan pertanian bertambah seluas 345,47 ha (BPS Sleman, 2013-2018).

Hal itu juga sesuai dengan apa yang tercantum dalam Peraturan Daerah Kabupaten Sleman Nomor 3 Tahun 2017 tentang Perubahan atas Peraturan Daerah Nomor 9 Tahun 2016 tentang Rencana Pembangunan Jangka Menengah Daerah Tahun 2015-2021 yang menyatakan salah satu isu strategis DIY adalah alih fungsi lahan yang berkembang pesat, dan tertinggi terjadi di Kabupaten Sleman dan Bantul. Tujuan dari penelitian ini adalah menganalisis persebaran kerapatan penduduk, keanekaragaman tanaman buah di pekarangan, hubungan kerapatan penduduk dengan keanekaragaman tanaman buah di pekarangan, adaptasi masyarakat dalam melestarikan tanaman buah dan pekarangan dan menyusun usulan pelestarian tanaman buah dan pekarangan di Kecamatan Godean dengan harapan agar tetap dapat menjaga lingkungan hidup dengan menjaga kawasan hijau di kawasan hunian.

\section{METODE PENELITIAN}

\section{Waktu dan Lokasi}

Penelitian dilakukan pada bulan MaretDesember 2019. Lokasi penelitian terletak di Kecamatan Godean, Kabupaten Sleman, Daerah Istimewa Yogyakarta yang disajikan dalam bentuk peta pada Gambar 1. Secara astronomis terletak

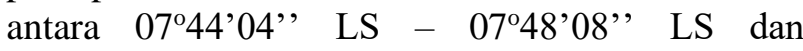
$110^{\circ} 15^{\prime} 44^{\prime}$ ' BT $-110^{\circ} 19^{\prime} 56^{\prime \prime}$ BT.

\section{Prosedur}

\section{Pengumpulan data}

Data yang dikumpulkan meliputi data Persebaran kerapatan penduduk, Keanekaragaman tanaman buah Adaptasi masyarakat dalam melestarikan tanaman buah dan pekarangan, serta data untuk penyusunan usulan pelestarian tanaman buah dan pekarangan.

Persebaran kerapatan penduduk dilakukan dengan mengumpulkan data sekunder dari BPS Sleman yang memuat informasi kerapatan penduduk per desa di Kecamatan Godean, juga memanfaatkan citra Pleides 2018 untuk pemetaan kerapatan penduduk. Untuk data keanekaragaman tanaman buah dilakukan dengan pengamatan langsung dengan melakukan inventarisasi jenis tanaman buah di pekarangan warga dan menghitung jumlah tiap jenis.

Pengamatan langsung untuk mengetahui adaptasi masyarakat dalam melestarikan tanaman buah dan pekarangan dilakukan inventarisasi seluruh jenis tanaman di pekarangan warga dan menghitung jumlah tiap jenis. Selanjutnya untuk menyusun usulan pelestarian tanaman buah dan pekarangan, dilakukan wawancara dengan warga yang terpilih menjadi sampel dan pemerintah desa se-Kecamatan Godean terkait usaha mereka untuk melestarikan tanaman buah dan pekarangan sebagai bahan untuk menyusun usulan pelestarian. 


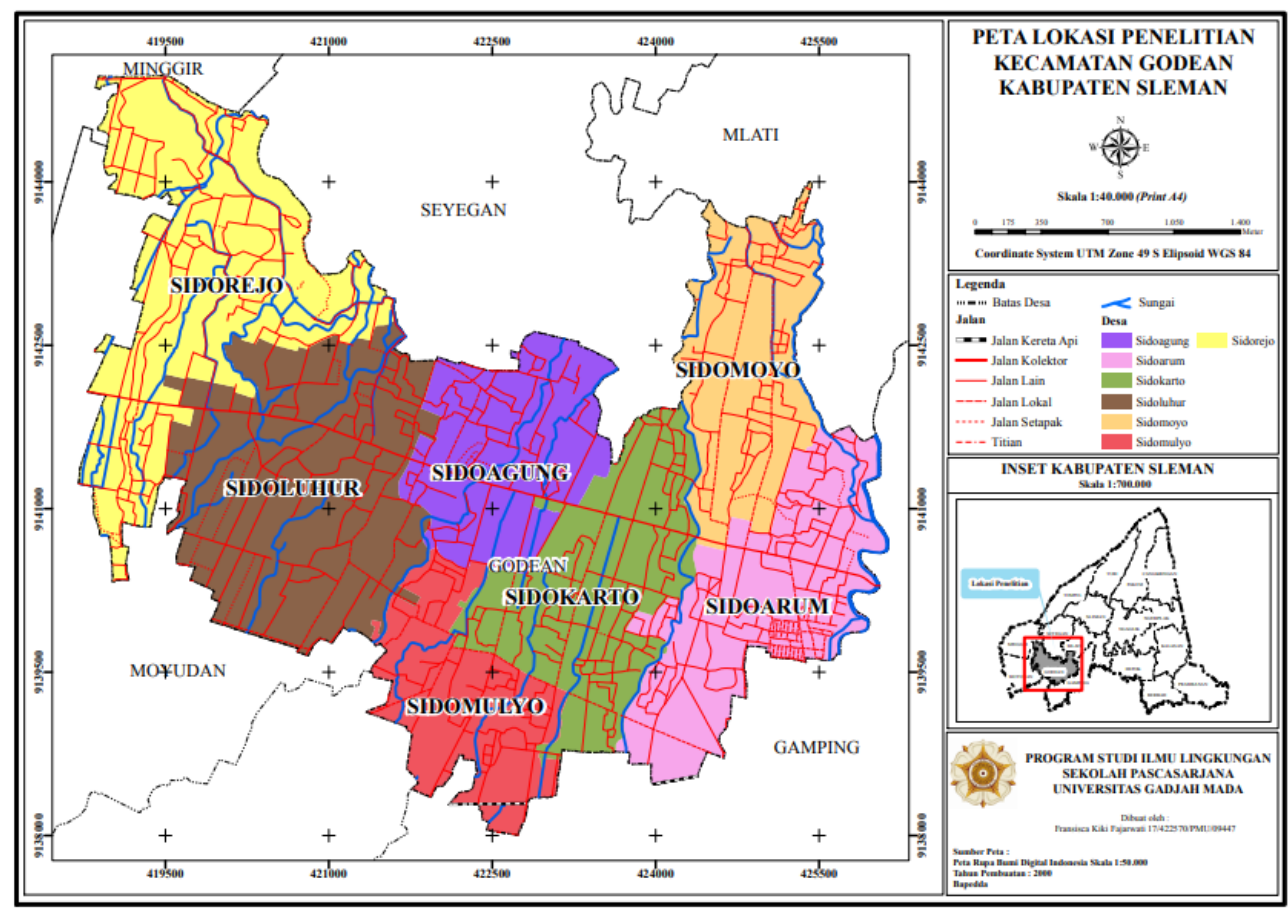

Gambar 1. Peta Lokasi Penelitian.

Tabel 1. Titik sampel hasil persilangan ketinggian dan kerapatan penduduk.

\begin{tabular}{cccc}
\hline Kerapatan penduduk (KP) & \multirow{2}{*}{ KP Rendah } & KP Sedang & \multirow{2}{*}{ KP Tinggi } \\
\cline { 1 - 3 } Ketinggian $(\mathrm{T})(\mathrm{mdpl})$ & KP rendah, T 41-160 & KP sedang, T 41-160 & KP tinggi, T 41-160 \\
T 41-160 & KP rendah, T 161-190 & KP sedang, T 161-190 & KP tinggi, T 161-190 \\
T 161-190 & KP rendah, T 191-253 & KP sedang, T 191-253 & KP tinggi, T 191-253 \\
T 191-253 &
\end{tabular}

Tabel 2. Keterangan lokasi penelitian.

\begin{tabular}{cl}
\hline Lokasi & \multicolumn{1}{c}{ Keterangan } \\
\hline 1 & Kerapatan penduduk rendah, ketinggian 191-253 mdpl, terletak di desa Sidorejo, barat sungai Soka. \\
2 & Kerapatan penduduk rendah, ketinggian 161-190 mdpl, terletak di desa Sidorejo, barat sungai Soka. \\
3 & $\begin{array}{l}\text { Kerapatan penduduk rendah, ketinggian 46-160 mdpl, terletak di desa Sidoluhur, di antara sungai Soka } \\
\text { dan Bedog. }\end{array}$ \\
4 & $\begin{array}{l}\text { Kerapatan penduduk sedang, ketinggian 191-253 mdpl, terletak di desa Sidomoyo, timur sungai Bedog. } \\
5\end{array}$ \\
& $\begin{array}{l}\text { Kerapatan penduduk sedang, ketinggian 161-190 mdpl, terletak di desa Sidoagung, di antara sungai } \\
6\end{array}$ \\
& Kerapatan penduduk tinggi, ketinggian 161-190 mdpl, terletak di desa Sidoarum, timur sungai Bedog. \\
\hline
\end{tabular}

\section{Penentuan titik sampel penelitian}

Penentuan sampel lokasi penelitian dengan melakukan tumpang susun (overlay) peta kerapatan penduduk dan ketinggian. Kerapatan penduduk memiliki tiga rentang yakni tinggi, sedang, dan rendah. Ketinggian tempat juga memiliki tiga rentang yakni tempat dengan ketinggian 41-160, 161-190, dan 191-253 mdpl. Pengambilan sampel harus mewakili persilangan ketinggian dan kerapatan penduduk, namun jika lokasi tidak terpenuhi maka tidak perlu diambil titik sampel. Lokasi penelitian juga ditambahkan dengan informasi batasan sungai yang membelah Kecamatan Godean dari utara ke selatan. Sungai yang dipakai adalah sungai Soka di bagian barat dan sungai Bedog di bagaian timur, maka ada tiga lokasi dibedakan per batasan sungai yakni di barat sungai Soka, di antara sungai Soka dan Bedog, serta di timur sungai Bedog. Titik sampel hasil persilangan ketinggian dan kerapatan penduduk ditampilkan dalam Tabel 1. Ada 6 titik sampel di lokasi penelitian yang sesuai dengan kriteria disajikan dalam Tabel 2. Peta titik sampel berdasarkan tumpang susun (overlay) peta kerapatan penduduk dan ketinggian tempat disajikan dalam Gambar 2.

Lokasi penelitian adalah lokasi kawasan permukiman kerena pekarangan berada di sekitar rumah warga. Lokasi terpilih kemudian dipilih 10 KK sebagai responden dengan ketentuan pekarangan yang memiliki tanaman buah minimal 3 jenis dan luas lahan termasuk dalam katagori pekarangan rumah kecil yakni di bawah $200 \mathrm{~m}^{2}$ sesuai Peraturan Menteri Pekerjaan Umum No. 05/PRT/M/2008. KK terpilih kemudian dilakukan inventarisasi jenis tanaman dan wawancara dengan pemilik pekarangan. 


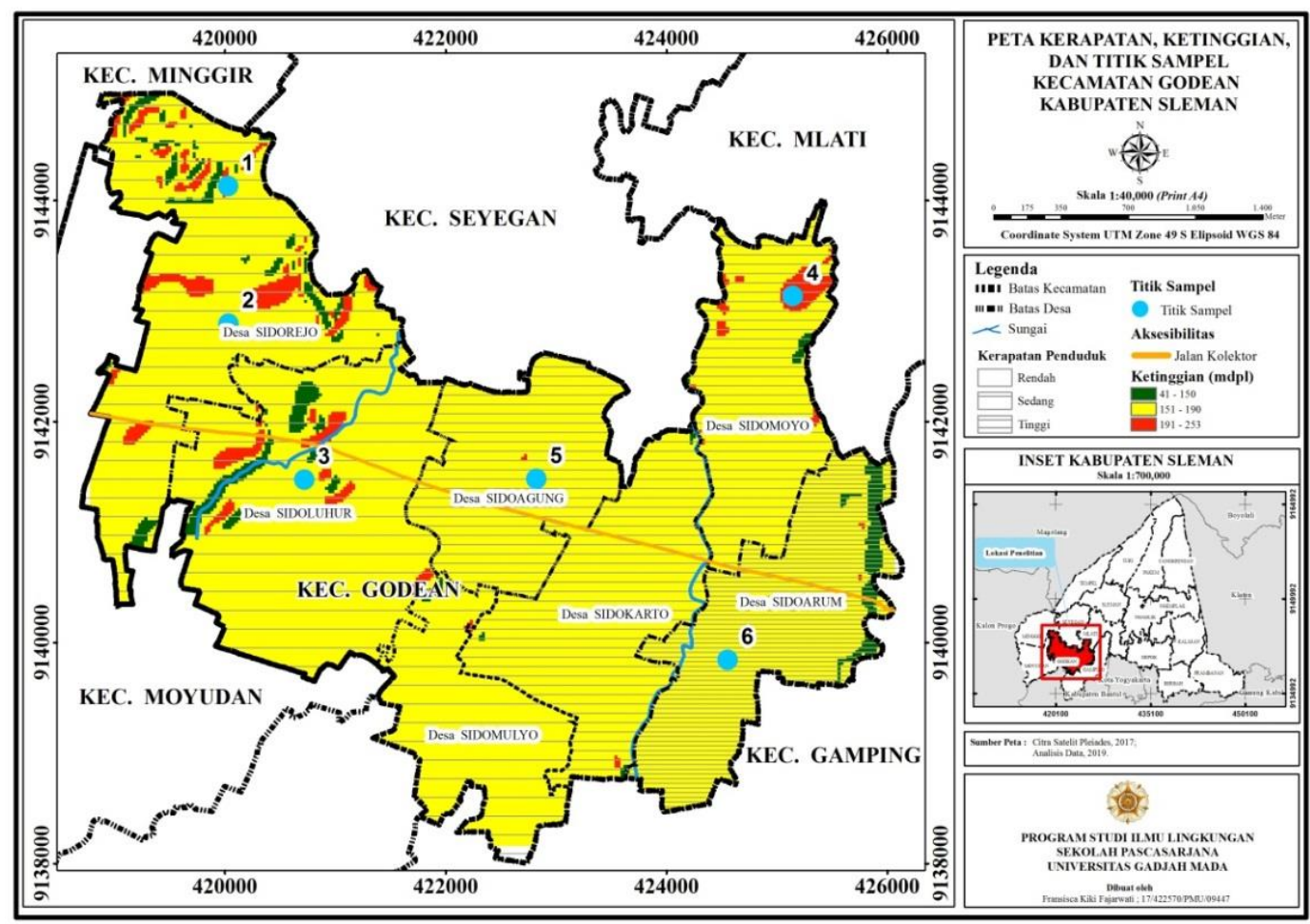

Gambar 2. Peta Kerapatan Penduduk, Ketinggian dan Titik Sampel.

Tabel 3. Kategori kerapatan penduduk.

\begin{tabular}{llll}
\hline No & Klasifikasi & Jiwa/km ${ }^{2}$ & Skor \\
\hline 1 & Rendah & $1.187-2.566$ & 1 \\
2 & Sedang & $2.567-3.945$ & 2 \\
3 & Tinggi & $3.946-5.324$ & 3 \\
\hline
\end{tabular}

Sumber: Analisis Peneliti, 2019

Tabel 4. Kerapatan penduduk per $\mathrm{km}^{2}$ dan klasifikasi kerapatan di Kecamatan Godean Tahun 2017.

\begin{tabular}{llcc}
\hline No. & \multicolumn{1}{c}{ Desa } & $\begin{array}{c}\text { Kerapatan } \\
\text { per km }\end{array}$ & $\begin{array}{c}\text { Klasifikasi } \\
\text { Kerapatan }\end{array}$ \\
\hline 1 & Sidorejo & 1.187 & Rendah \\
2 & Sidoluhur & 1.842 & Rendah \\
3 & Sidomulyo & 2.377 & Rendah \\
4 & Sidoagung & 2.742 & Sedang \\
5 & Sidokarto & 3.529 & Sedang \\
6 & Sidoarum & 5.324 & Tinggi \\
7 & Sidomoyo & 2.736 & Sedang \\
Total 1 Kecamatan & 2.684 & Sedang \\
\hline
\end{tabular}

Sumber: BPS Sleman, 2018 dan Hasil analisis peneliti, 2019

\section{Analisis data}

Analisis data dilakukan untuk data persebaran kerapatan penduduk, hubungan kerapatan penduduk dengan keanekaragaman tanaman buah, analisis adaptasi masyarakat dalam melestarikan tanaman buah dan pekarangan serta dalam hal menyusun usulan pelestarian tanaman buah dan pekarangan

Analisis persebaran kerapatan penduduk dilakukan dengan mengumpulkan data kerapatan penduduk per desa di Kecamatan Godean, kemudian diklasifikasi dalam rentang rendah, sedang, dan tinggi, lalu dipetakan dan dianalisis faktor penyebab persebaran kerapatan penduduk.
Penentuan nilai rentang kerapatan penduduk menggunakan rumus:

$$
\begin{aligned}
& \text { Nilai rentang }(N R)=\frac{(\Sigma \text { Nilai Tertinggi }-\Sigma \text { Nilai Terendah })}{3} \\
& \text { Nilai rentang }(N R)=\frac{(5.324-1.187)}{3}=1.379
\end{aligned}
$$

Hasil perhitungan rentang kerapatan penduduk disajikan dalam Tabel 3. Kerapatan penduduk per $\mathrm{km}^{2}$ dan klasifikasi kerapatan penduduk di Kecamatan Godean disajikan dalam Tabel 4.

\section{Keanekaragaman tanaman buah}

Analisis dilakukan dengan menghitung indeks keanekaragaman, kemerataan, dan dominansi menggunakan rumus dan dilakukan analisis faktor yang mempengaruhi perhitungan indeks yang diperoleh. Perhitungan dilakukan dengan mengacu Suhartini dkk (2015):

Indeks Keanekaragaman:

$$
\left(\mathrm{H}^{\prime}\right)=-\sum_{l=1}^{n} \frac{n i}{N} \operatorname{Ln} \frac{n i}{N}
$$

Keterangan:

$\mathrm{H}^{\prime}=$ indeks keanekaragaman Shannon-Wiener

ni $=$ jumlah individu jenis ke-i

$\mathrm{N}=$ jumlah individu dari seluruh jenis yang ada dalam plot penelitian

Kriteria penilaian indeks keanekaragaman jenis sesuai Wilhm dan Dorris (Insafitri, 2010) yaitu:

$\mathrm{H}^{\prime}<1=$ keanekaragaman rendah

$1<\mathrm{H}^{\prime}<3=$ keanekaragaman sedang

$\mathrm{H}^{\prime}>3=$ keanekaragaman tinggi 
Indeks Kemerataan/ Evenness (E):

$$
(\mathrm{E})=\frac{H^{\prime}}{\operatorname{Ln}(S)}
$$

Keterangan:

$\mathrm{E}=$ indeks kemerataan jenis

$\mathrm{H}^{\prime}$ = indeks keanekaragaman Shannon-Wiener

$\mathrm{S}=$ jumlah jenis

Kriteria penilaian indeks kemerataan atau eveness mengacu pada Insafitri (2010) adalah:

$\mathrm{E}<0,4 \quad=$ kemerataan rendah

$0,4<\mathrm{E}<0,6=$ kemerataan sedang

$\mathrm{E}>0,6 \quad=$ kemerataan tinggi

Indeks Dominansi (C):

$$
\text { (C) }=\sum_{i=1}^{n}\left(\frac{n i}{N}\right)^{2}
$$

Keterangan:

$\mathrm{C}=$ Indeks dominansi

$\mathrm{ni}=$ Jumlah individu ke-i

$\mathrm{N}=$ Jumlah total individu

Kriteria penilaian indeks dominansi menurut Hoek, dkk (2014) adalah:

$0,00<\mathrm{C}<0,50=$ dominansi rendah

$0,50<\mathrm{C}<0,75=$ dominansi sedang

$0,75<\mathrm{C}<1,00=$ dominansi tinggi

Untuk analisisis hubungan kerapatan penduduk dengan keanekaragaman tanaman buah maka dilakukan uji korelasi uji beda Chi Square menggunakan program SPSS. Untuk analisis adaptasi masyarakat dalam melestarikan tanaman buah dan pekarangan, dilakukan dengan membandingkan jenis tanaman lain selain tanaman buah yang ditemukan di pekarangan per kerapatan penduduk. Selanjutnya untuk menyusun usulan pelestarian tanaman buah dan pekarangan, maka dilakukan dengan mempertahankan usaha pemerintah dan warga yang dirasa masih relevan dan efektif, memperbaiki atau menghilangkan yang kurang efektif dan menyusun usulan baru yang merupakan ide dari peneliti berdasarkan permasalahan yang ditemukan di lapangan.

\section{HASIL DAN PEMBAHASAN}

\section{Persebaran Kerapatan Penduduk}

Kerapatan penduduk per desa di Kecamatan Godean disajikan dalam bentuk peta disajikan pada Gambar 3. Kerapatan penduduk semakin ke barat (menjauhi Kota Yogyakarta) memiliki angka kerapatan penduduk semakin rendah. Hal tersebut disebabkan pertama karena faktor fisik, dimana desa Sidoluhur dan Sidorejo dengan kerapatan penduduk rendah memiliki bentang alam berupa dataran tinggi berupa bukit yang yang termasuk dalam daerah sukar dibangun dibandingkan dengan daerah seperti dataran rendah, pandang rumput, pinggir sungai dan lain-lain yang mudah dibangun (Waugh, 2014). Faktor lain yang mempengaruhi adalah adanya sumber daya alam ekonomi. Semakin ke timur adalah daerah yang semakin dekat dengan pusat kota yakni Kota Yogyakarta sebagai pusat perekonomian, pendidikan, budaya, dan lain-lain.

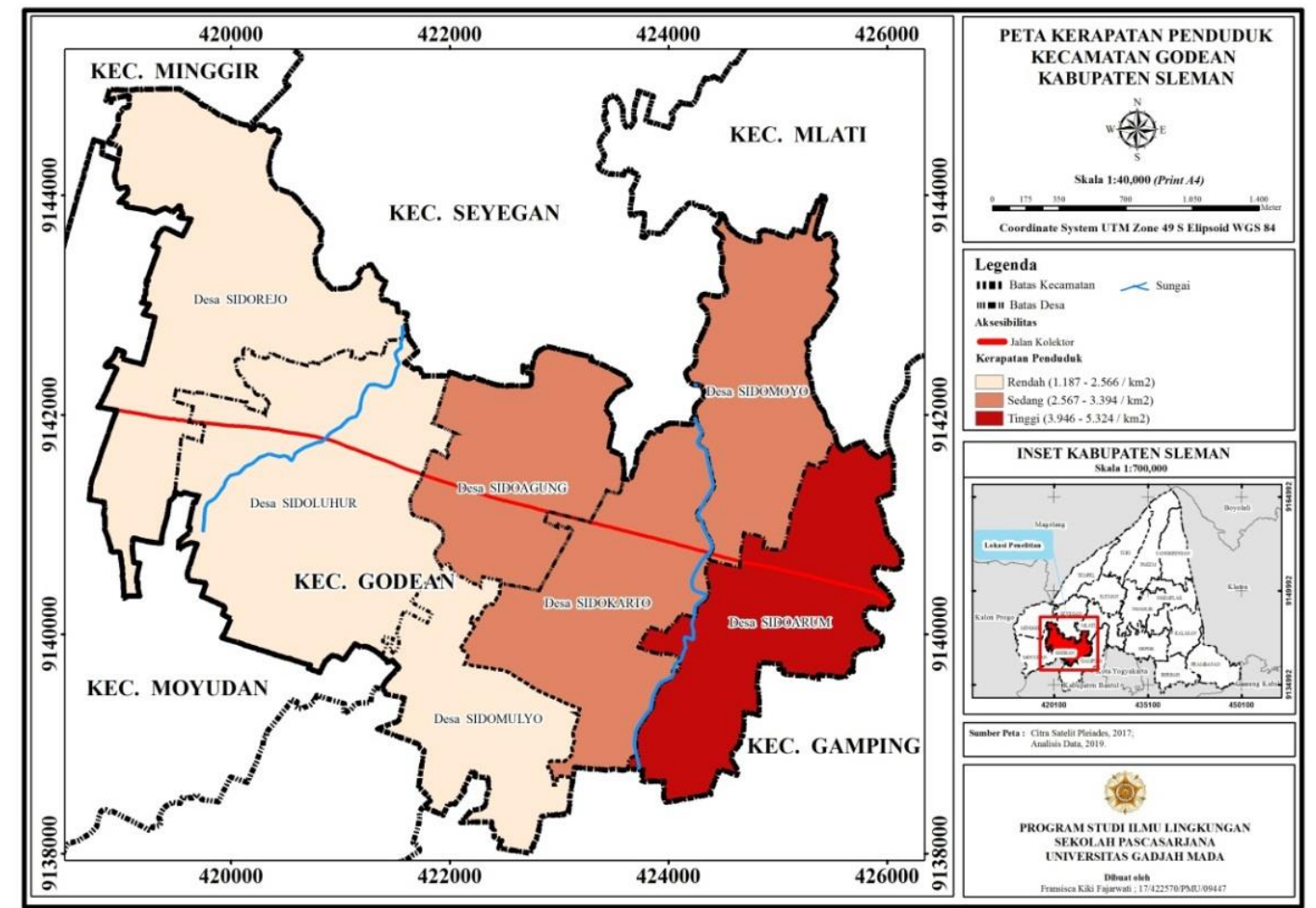

Gambar 3. Peta Kerapatan Penduduk per desa di Kecamatan Godean. Sumber: Hasil Analisis Peneliti, 2019. 
Daerah Kecamatan Godean semakin ke barat dekat dengan daerah pedesaan yakni Kecamatan Moyudan Kabupaten Sleman yang lebih sepi dibandingkan dengan daerah kota Yogyakarta, dan jika ditarik ke barat lagi masuk daerah Kulonprogo yang merupakan daerah perbukitan yang lebih sepi lagi, jauh dari pusat perkonomian, pendidikan, budaya dan lain-lain. Menurut Waugh (2014), manusia cenderung bergerak ke arah daerah yang memiliki aktivitas ekonomi tinggi. Faktor lain yang berpengaruh adalah fasilitas komunikasi dan transportasi. Desa Sidorejo, Sidoluhur dan Sidomulyo dengan kerapatan penduduk rendah termasuk dalam daerah terpencil jika dibandingkan dengan Sidoarum yang lebih mendekatai kota Yogyakarta dan memiliki aksesbilitas yang lebih mudah. Menurut Waugh (2014), aksesibilitas merupakan aspek penting dalam menentukan lokasi aktivitas ekonomi.

\section{Keanekaragaman Tanaman Buah di Pekarangan}

Nilai indeks keanekaragaman, kemerataan, dan dominansi tanaman buah dibedakan per kerapatan penduduk disajikan dalam Tabel 5. Angka indeks yang didapatkan tidak memiliki selisih yang sangat signifikan yakni masing-masing dalam satu rentang tertentu. Selisih yang sedikit tersebut, namun dapat diketahui semakin rapat penduduk maka semakin rendah indeks keanekaragaman dan indeks kemerataan tanaman buah serta semakin tinggi nilai indeks dominansi tanaman buah, semakin sedikit jumlah jenis tanaman buah yang ditemukan. Hal tersebut bisa menjadi bukti semakin banyak jumlah penduduk pada lahan dengan luas yang tetap mengakibatkan terjadinya alih fungsi lahan menjadi lahan terbangun termasuk dari pekarangan menjadi rumah yang berdampak pada menghilangkan sejumlah tanaman yang ada di pekarangan termasuk tanaman buah karena manusia membutuhkan rumah sebagai papan atau tempat tinggal.

Nilai indeks keanekaragaman, kemerataan dan dominansi tanaman buah dibedakan per ketinggian tempat disajikan dalam Tabel 6. Angka indeks yang didapatkan tidak memiliki selisih yang sangat signifikan yakni masing-masing dalam satu rentang tertentu, namun dapat diketahui bahwa semakin tinggi suatu tempat, semakin tinggi indeks keanekaragaman dan indeks kemerataan tanaman buah serta semakin rendah nilai indeks dominansi tanaman buah dan semakin banyak jumlah jenis tanaman buah yang ditemukan walaupun pada ketinggian 41-160 dan 161-190 mdpl memiliki jumlah jenis yang sama dan hanya memiliki selisih jumlah satu jenis dengan ketinggian tempat 191253 mdpl.Menurut Waugh (2014), faktor yang mempengaruhi kerapatan penduduk suatu wilayah salah satunya adalah fakor fisik dimana daerah dengan bentang alam yang mudah dibangun (dataran rendah, padang rumput dan pinggir sungai) cenderung memiliki jumlah penduduk yang lebih banyak dibanding dengan daerah yang sukar dibangun (dataran tinggi, pegunungan dengan lereng terjal, kawasan vulkanik aktif). Kecamatan Godean dengan ketinggian tempat 191-253 mdpl yang merupakan lokasi paling tinggi, salah satunya adalah daerah bukit juga memiliki kerapatan penduduk dalam rentang rendah. Hal ini semakin menunjukkan adanya semakin banyak manusia di suatu wilayah mempengaruhi kenakeragaman tanaman buah di wilayah tersebut.

Tabel 5. Nilai Indeks Keanekaragaman, Kemerataan, dan Dominansi dibedakan per kerapatan penduduk.

\begin{tabular}{ccccccc}
\hline No. & $\begin{array}{c}\text { Angka kerapatan } \\
\text { penduduk dan } \\
\text { keterangan } \\
\text { rentang }\end{array}$ & $\begin{array}{c}\text { Lokas } \\
\mathrm{i}\end{array}$ & $\begin{array}{c}\text { Jumlah jenis } \\
\text { tanaman } \\
\text { buah }\end{array}$ & $\begin{array}{c}\text { Nilai Indeks } \\
\text { Keanekaragaman } \\
\text { dan Keterangan } \\
\text { Rentang }\end{array}$ & $\begin{array}{c}\text { Nilai Indeks } \\
\text { Kemerataan dan } \\
\text { Keterangan } \\
\text { Rentang }\end{array}$ & $\begin{array}{c}\text { Nilai Indeks } \\
\text { Dominansi dan } \\
\text { Keterangan } \\
\text { Rentang }\end{array}$ \\
\hline 1 & 1.584 (Rendah) & $1,2,3$ & 26 & 2,64 (Sedang) & 0,81 (Tinggi) & 0,11 (Rendah) \\
2 & 2.739 (Sedang) & 4,5 & 22 & 2,19 (Sedang) & 0,71 (Tinggi) & 0,21 (Rendah) \\
3 & 5.324 (Tinggi) & 6 & 19 & 1,99 (Sedang) & 0,68 (Tinggi) & 0,24 (Rendah) \\
\hline
\end{tabular}

Tabel 6. Nilai Indeks Keanekaragaman, Kemerataan, dan Dominansi dibedakan per ketinggian tempat.

\begin{tabular}{ccccccc}
\hline No. & $\begin{array}{c}\text { Ketinggian } \\
\text { Tempat } \\
(\mathrm{mdpl})\end{array}$ & Lokasi & $\begin{array}{c}\text { Jumlah jenis } \\
\text { tanaman } \\
\text { buah }\end{array}$ & $\begin{array}{c}\text { Nilai Indeks } \\
\text { Keanekaragaman } \\
\text { dan Keterangan } \\
\text { Rentang }\end{array}$ & $\begin{array}{c}\text { Nilai Indeks } \\
\text { Kemerataan dan } \\
\text { Keterangan } \\
\text { Rentang }\end{array}$ & $\begin{array}{c}\text { Nilai Indeks } \\
\text { Dominansi dan } \\
\text { Keterangan } \\
\text { Rentang }\end{array}$ \\
\hline 1 & $46-160$ & 1,4 & 23 & 2,23 (Sedang) & 0,72 (Tinggi) & 0,19 (Rendah) \\
2 & $161-190$ & $2,5,6$ & 23 & 2,38 (Sedang) & 0,76 (Tinggi) & 0,17 (Rendah) \\
3 & $191-253$ & 3 & 24 & 2,66 (Sedang) & 0,84 (Tinggi) & 0,11 (Rendah) \\
\hline
\end{tabular}


Nilai indeks keanekaragaman, kemerataan, dan dominansi tanaman buah dibedakan per batasan sungai disajikan dalam Tabel 7. Angka indeks yang didapatkan tidak memiliki selisih yang sangat signifikan yakni masing-masing dalam satu rentang. Lokasi diurutkan dari timur ke barat (menjauhi Kota Yogyakarta) yakni lokasi terletak di timur sungai Bedog, lokasi di antara sungai Soka dan Bedog serta lokasi di barat sungai Soka diketahui memiliki nilai angka indeks keanekaragaman dan indeks kemerataan tanaman buah semakin rendah serta nilai angka indeks dominansi tanaman buah semakin tinggi.

Hasil penelitian ini dapat menjadi bukti bahwa semakin lokasi dekat dengan pusat kota Yogyakarta, maka semakin memiliki nilai angka indeks keanekaragaman dan kemerataan tanaman buah semakin rendah serta nilai angka indeks dominansi tanaman buah semakin tinggi. Hal tersebut juga sesuai dengan jumlah jenis yang ditemukan. Semakin lokasi mendekati pusat kota Yogyakarta, semakin sedikit jumlah jenis tanaman buah yang ditemukan. Hal tersebut sesuai dengan tinjauan pustaka menurut Insafitri (2010), semakin kecil nilai indeks keanekaragaman (H') maka indeks kemerataan (E) juga akan semakin kecil, yang mengisyaratkan semakin tinggi indeks dominansi suatu spesies terhadap spesies lain. Menurut Waugh (2014) faktor yang mempengaruhi kerapatan penduduk suatu wilayah antara lain adanya sumber daya alam ekonomi, komunikasi yang berkaitan dengan fasilitas komunikasi dan transportasi serta aksesbilitas. Semakin ke arah kota, aksesbilitas semakin mudah, semakin rapat penduduk dan semakin rendah nilai keanekaragaman tanaman buah.

\section{Hubungan Kerapatan Penduduk dengan Keanekaragaman Tanaman Buah}

Hubungan kerapatan penduduk dengan indeks keanekaragaman tanaman buah dapat dianalisis dengan mengetahui nilai indeks keanekaragaman masing-masing rentang kerapatan penduduk. Nilai indeks keanekaragaman disajikan dalam Tabel 8.

Kerapatan penduduk memiliki hubungan/ berpengaruh pada nilai indeks keanekaragaman tanaman buah dengan sifat yakni hubungan terbalik. Semakin tinggi kerapatan penduduk, semakin rendah nilai indeks keanekaragaman tanaman buah. Tingkat hubungan/ pengaruh yang dimiliki tidak terlalu signifikan, hal tersebut dibuktikan dengan uji statistika Chi Square tidak dapat dilakukan karena semua rentang kerapatan penduduk rendah, sedang dan tinggi memiliki rentang nilai indeks keanekaragaman yang sama yakni sedang walau memiliki nilai angka yang berbeda. Menurut BAPPENAS Deputi Bidang Sumber Daya Alam dan Lingkungan Hidup (2014), jumlah penduduk yang tinggi memerlukan sandang, pangan, papan serta ruang yang berasal dari alam yang berkaitan sangat erat dengan keanekaragaman hayati. Orang membutuhkan lahan untuk didirikan rumah sebagai tempat tinggal, maka orang melakukan alih fungsi lahan termasuk dari pekarangan menjadi lahan terbangun berupa rumah yang kemudian menghilangkan berbagai macam tumbuhan yang kemudian menurunkan nilai

Tabel 7. Nilai indeks keanekaragaman, kemerataan, dan dominansi dibedakan per batasan sungai.

\begin{tabular}{clccccc}
\hline No. & Lokasi penelitian & Lokasi & $\begin{array}{c}\text { Jumlah } \\
\text { jenis } \\
\text { tumbuhan } \\
\text { buah }\end{array}$ & $\begin{array}{c}\text { Nilai Indeks } \\
\text { Keanekaragaman } \\
\text { dan Keterangan } \\
\text { Rentang }\end{array}$ & $\begin{array}{c}\text { Nilai Indeks } \\
\text { Kemerataan dan } \\
\text { Keterangan } \\
\text { Rentang }\end{array}$ & $\begin{array}{c}\text { Nilai Indeks } \\
\text { Dominansi dan } \\
\text { Keterangan } \\
\text { Rentang }\end{array}$ \\
\hline 1 & Barat Sungai Soka & 1,2 & 27 & 2,62 (Rendah) & 0,80 (Tinggi) & 0,11 (Rendah) \\
2 & $\begin{array}{l}\text { Antara Sungai Soka } \\
\text { dan Sungai Bedog }\end{array}$ & $3,4,5$ & 22 & 2,35 (Rendah) & 0,75 (Tinggi) & 0,18 (Rendah) \\
3 & Timur Sungai Bedog & 6 & 19 & 1,99 (Rendah) & 0,68 (Tinggi) & 0,24 (Rendah) \\
\hline
\end{tabular}

Tabel 8. Tabulasi hubungan kerapatan penduduk dengan keanekaragaman tanaman buah.

\begin{tabular}{cccccc}
\hline No. & $\begin{array}{c}\text { Angka kerapatan } \\
\text { penduduk }\end{array}$ & $\begin{array}{c}\text { Keterangan } \\
\text { lokasi }\end{array}$ & $\begin{array}{c}\text { Rentang kerapatan } \\
\text { penduduk }\end{array}$ & $\begin{array}{c}\text { Nilai Indeks } \\
\text { Keanekaragaman }\end{array}$ & $\begin{array}{c}\text { Rentang Indeks } \\
\text { Keanekaragaman }\end{array}$ \\
\hline 1 & 1.584 & $1,2,3$ & Rendah & 2,64 & Sedang \\
2 & 2.739 & 4,5 & Sedang & 2,19 & Sedang \\
3 & 5.324 & 6 & Tinggi & 1,99 & Sedang \\
\hline
\end{tabular}

Tabel 9. Tabulasi hubungan kerapatan penduduk dengan indeks kemerataan tanaman buah.

\begin{tabular}{cccccc}
\hline No. & $\begin{array}{c}\text { Angka kerapatan } \\
\text { penduduk }\end{array}$ & Lokasi & $\begin{array}{c}\text { Rentang kerapatan } \\
\text { penduduk }\end{array}$ & $\begin{array}{c}\text { Nilai Indeks } \\
\text { Kemerataan }\end{array}$ & $\begin{array}{c}\text { Rentang Indeks } \\
\text { Kemerataan }\end{array}$ \\
\hline 1 & 1.584 & $1,2,3$ & Rendah & 0,81 & Tinggi \\
2 & 2.739 & 4,5 & Sedang & 0,71 & Tinggi \\
3 & 5.324 & 6 & Tinggi & 0,68 & Tinggi \\
\hline
\end{tabular}


Tabel 10. Tabulasi hubungan kerapatan penduduk dengan indeks dominansi tanaman buah.

\begin{tabular}{cccccc}
\hline No. & $\begin{array}{c}\text { Angka kerapatan } \\
\text { penduduk }\end{array}$ & $\begin{array}{c}\text { Keterangan } \\
\text { lokasi }\end{array}$ & $\begin{array}{c}\text { Rentang kerapatan } \\
\text { penduduk }\end{array}$ & $\begin{array}{c}\text { Nilai indeks } \\
\text { dominansi }\end{array}$ & $\begin{array}{c}\text { Rentang indeks } \\
\text { dominansi }\end{array}$ \\
\hline 1 & 1.584 & $1,2,3$ & Rendah & 0,11 & Rendah \\
2 & 2.739 & 4,5 & Sedang & 0,21 & Rendah \\
3 & 5.324 & 6 & Tinggi & 0,24 & Rendah \\
\hline
\end{tabular}

Tabel 11. Rekapitulasi jenis tanaman yang ditemukan di pekarangan Kecamatan Godean per kerapatan penduduk.

\begin{tabular}{|c|c|c|c|c|c|c|c|c|}
\hline \multirow[t]{2}{*}{ Jenis tanaman } & \multicolumn{6}{|c|}{$\begin{array}{l}\text { Jumlah jenis tanaman per satuan KK } \\
\text { yang ditemukan per kerapatan penduduk }\end{array}$} & \multicolumn{2}{|c|}{ Jumlah } \\
\hline & & dah & & ang & & nggi & Jumlah & Persen \\
\hline Tanaman buah & 10 & $31,9 \%$ & 10 & $32,7 \%$ & 10 & $29,4 \%$ & 30 & $31,3 \%$ \\
\hline Tanaman obat & 2,67 & $8,5 \%$ & 3,5 & $11,4 \%$ & 4 & $11,7 \%$ & 10,17 & $10,6 \%$ \\
\hline Tanaman sayur & 7 & $22,3 \%$ & 5 & $16,3 \%$ & 9 & $26,5 \%$ & 21 & $21,9 \%$ \\
\hline Tanaman hias & 4 & $12,8 \%$ & 6,5 & $21,3 \%$ & 6 & $17,7 \%$ & 16,5 & $17,2 \%$ \\
\hline Tanaman keras & 7,67 & $24,5 \%$ & 5,6 & $18,3 \%$ & 5 & $14,7 \%$ & 18,27 & $19 \%$ \\
\hline Total & 31,34 & $100 \%$ & 30,6 & $100 \%$ & 34 & $100 \%$ & 95,94 & $100 \%$ \\
\hline
\end{tabular}

keanekaragaman tumbuhan tertentu yang berujung pada kelangkaan.

Hubungan kerapatan penduduk dengan nilai indeks kemerataan tanaman buah dapat dianalisis dengan mengetahui nilai indeks kemerataan masing-masing rentang kerapatan penduduk. Nilai indeks kemerataan disajikan dalam Tabel 9. Kerapatan penduduk memiliki hubungan/ berpengaruh pada nilai indeks kemerataan tanaman buah dengan sifat yakni hubungan terbalik.

Semakin tinggi kerapatan penduduk, semakin rendah nilai indeks kemerataan tanaman buah. Tingkat hubungan/ pengaruh yang dimiliki tidak terlalu signifikan, hal tersebut dibuktikan dengan uji statistika Chi Square tidak dapat dilakukan karena semua rentang kerapatan penduduk rendah, sedang dan tinggi memiliki rentang nilai indeks kemerataan yang sama yakni tinggi walau memiliki nilai angka yang berbeda. Nilai indeks kemerataan yang tinggi tersebut menandakan bahwa komunitas tanaman buah di Kecamatan Godean seimbang yakni memiliki ukuran kesamaan jumlah individu antar spesies dalam suatu komunitas yang tinggi. Tanaman buah di Kecamatan Godean memiliki jumlah individu antar spesies dengan kemiripan tinggi/ persebarannya merata yang menandakan besarnya derajat keseimbangan komunitas tanaman buah.

Hubungan kerapatan penduduk dengan nilai indeks dominansi tanaman buah dapat dianalisis dengan mengetahui nilai indeks dominansi masingmasing rentang kerapatan penduduk. Nilai indeks dominansi disajikan dalam Tabel 10. Kerapatan penduduk memiliki hubungan/ berpengaruh pada nilai indeks dominansi tanaman buah dengan sifat yakni berbanding lurus. Semakin tinggi kerapatan penduduk, semakin tinggi pula nilai indeks dominansi tanaman buah. Tingkat hubungan/ pengaruh yang dimiliki tidak terlalu signifikan, hal tersebut dibuktikan dengan uji statistika Chi Square tidak dapat dilakukan karena semua rentang kerapatan penduduk rendah, sedang, dan tinggi memiliki rentang nilai indeks dominansi yang sama yakni rendah walau memiliki nilai angka yang berbeda. Nilai indeks dominansi rendah yang memiliki nilai angka semakin mendekati 0 tersebut menandakan bahwa komunitas tanaman buah di Kecamatan Godean cenderung tidak ada individu yang mendominasi komunitas.

\section{Adaptasi Masyarakat dalam Melestarikan Tanaman Buah dan Pekarangan}

Rekapitulasi jenis tanaman yang ditemukan di pekarangan Kecamatan Godean per kerapatan penduduk sebagai bahan untuk analisis disajikan dalam Tabel 11. Tanaman dominan setelah tanaman buah pada lokasi dengan kerapatan penduduk rendah adalah tanaman keras dengan jumlah persen yakni $25 \%$ dari total jenis tanaman yang ditemui pada lokasi dengan kerapatan penduduk rendah. Tanaman dominan setelah tanaman buah pada lokasi dengan kerapatan penduduk sedang adalah tanaman hias dengan jumlah persen yakni $21 \%$ dari total jenis tanaman yang ditemui pada lokasi dengan kerapatan penduduk sedang. Tanaman dominan setelah tanaman buah pada lokasi dengan kerapatan penduduk tinggi adalah tanaman sayur dengan jumlah persen yakni $26 \%$ dari total jenis tanaman yang ditemui pada lokasi dengan kerapatan penduduk tinggi. Jenis tanaman pada lokasi dengan kerapatan penduduk rendah memiliki jenis tanaman dominan yakni tanaman keras yang membutuhkan banyak tempat untuk tanaman ini tumbuh dan berkembang. Tanaman keras ini dimanfaatkan warga yakni batang tanaman untuk bahan bangunan atau dijual. Jenis tanaman pada lokasi dengan kerapatan penduduk sedang sudah terjadi adaptasi yakni dominan adalah tanaman hias. Hal tersebut sesuai dengan apa yang dinyatakan oleh Sarwadi dan Irwan (2018) yakni 
banyak dijumpai terbatasnya lahan pekarangan, hanya diisi dengan tanaman hias saja.

Adaptasi warga pada kerapatan penduduk sedang adalah dengan menanam tanaman hias yang dapat memberi keindahan rumah, belum mengarah pada tanaman sayur. Beberapa rumah sudah menanam tanaman sayur, namun yang lebih dominan adalah menanam tanaman hias. Jenis tanaman pada lokasi dengan kerapatan penduduk tinggi terjadi adaptasi yakni dominan berupa tanaman sayur. Hal tersebut menunjukkan bahwa pemerintah dan warga mendukung apa yang diperjuangkan oleh pemerintah yakni tanaman pekarangan saat ini khusunya di wilayah perkotaan yang memiliki kerapatan penduduk tinggi diarahkan pada konsep landskap produktif untuk mendukung tercapainya ketahanan pangan nasional (Sarwadi dan Irwan, 2018).

Hal tersebut juga dapat dibuktikan dengan adanya banyak program optimalisasi lahan pekarangan dari pemerintah desa di desa Sidoarum yang merupakan lokasi dengan kerapatan penduduk tinggi antara lain menanam sayuran dalam polibeg serta pembuatan taman desa dengan menanam tanaman sayur, obat, dan hias yang dilombakan sehingga memotivasi warga untuk melestarikan pekarangan. Berdasarkan hal tersebut, maka dapat diketahui bahwa warga dan pemerintah desa pada lokasi dengan kerapatan penduduk tinggi sudah memiliki kesadaran akan optimalisasi lahan pekarangan dengan menerapkan konsep landskap produktif yakni menanam tanaman yang dapat mendukung katahanan pangan. Hal tesebut juga berlaku secara umum di Kecamatan Godean yang memiliki jenis tanaman dominan setelah tanaman buah adalah tanaman sayur dengan presentase $21,9 \%$ dari keseluruhan jenis tanaman di pekarangan Kecamatan Godean.

\section{Usulan Pelestarian Tanaman Buah dan Pekarangan untuk mendukung Kawasan Hijau di Kawasan Hunian}

Data berupa bentuk usaha, kendala, ancaman bencana, pendukung serta rencana kedepan yang telah dilakukan oleh pemerintah dan warga digunakan sebagai acuan menjaga lingkungan hidup yakni mempertahankan kawasan hijau di kawasan hunian dengan menyusun bentuk pelestarian tanaman buah dan pekarangan. Usulan pelestarian tersebut antara lain mengembangkan tanaman buah dalam pot (tabulampot), mempertahankan pembagian bibit tanaman buah, menindaklanjuti pembuatan kebun buah yang dikelola oleh desa, melanjutkan lomba pembuatan taman desa antar dusun, dan diversifikasi tanaman pekarangan. Usulan lain yang mendukung adalah memberi modal dan mencarikan jaringan pemasaran buah, membuat peraturan hukuman untuk orang yang mencuri di kebun buah milik desa, membungkus buah dengan plastik, menerapkan teknologi memanen air hujan untuk mengatasi kekeringan dan aliran permukaan yang deras, sosialisasi dan menerapkan konsep rumah susun dan memberi pupuk kandang pada tanah yang kurang subur, dan kaderisasi kelompok wanita tani (KWT).

\section{KESIMPULAN}

Kerapatan penduduk di Kecamatan Godean semakin ke bagian timur (mendekati Kota Yogyakarta) memiliki angka semakin tinggi. Semakin rapat penduduk maka semakin rendah indeks keanekaragaman dan kemerataan, semakin tinggi nilai indeks dominansi, semakin sedikit jumlah jenis tanaman buah yang ditemukan, serta semakin sedikit kawasan hijau di kawasan hunian. Lokasi dengan kerapatan penduduk semakin tinggi terjadi adaptasi pelestarian kawasan hijau dengan melestarikan tanaman buah dan pekarangan yang mendukung konsep lanskap produktif.

Usulan pelestarian tanaman buah dan pekarangan untuk menjaga lingkungan dengan mempertahankan kawasan hijau di kawasan hunian dengan mengembangkan tanaman buah dalam pot (tabulampot), mempertahankan pembagian bibit tanaman buah, menindaklanjuti pembuatan kebun buah yang dikelola oleh desa, melanjutkan lomba pembuatan taman desa antar dusun, dan diversifikasi tanaman pekarangan.

\section{DAFTAR PUSTAKA}

Ajesh, T.P., Naseef, S.A.A., and Kumuthakalavalli, R., 2012. Ethnobotanical Documentation of Wild Edible Fruits Used by Muthuvan tribes of Idukki, Kerala-India. International Journal of Pharmacy Biology Science, 3(3):479-487.

Ali, S., 2016. Model Kompensasi Lingkungan Pada Perumahan Ditinjau dari Aspek Vegetasi dalam Serapan Karbon Dioksida di Kabupaten Sleman, Daerah Istimewa Yogyakarta. Disertasi Ilmu Lingkungan. Universitas Gadjah Mada.

BAPPENAS Deputi Bidang Sumber Daya Alam dan Lingkungan Hidup (Direktorat Pengendalian Sumberdaya Alam dan Lingkungan Hidup). 2014. Wilayah Kritis Keanekaragaman Hayati di Indonesia: Instrumen Penilaian dan Pemindaian Indikatif/ Cepat bagi Pengambil Kebijakan. 
Jakarta: United Nation Development Program (UNDP) INS/01/024 Project-IDEN.

BPS Sleman, 2013. Kecamatan Godean dalam Angka 2013. Sleman: BPS Sleman.

BPS Sleman. 2014. Kecamatan Godean dalam Angka 2014. Sleman: BPS Sleman.

BPS Sleman, 2015. Kecamatan Godean dalam Angka 2015. Sleman: BPS Sleman.

BPS Sleman, 2016. Kecamatan Godean dalam Angka 2016. Sleman: BPS Sleman.

BPS Sleman, 2017. Kecamatan Godean dalam Angka 2017. Sleman: BPS Sleman.

BPS Sleman, 2018. Kecamatan Godean dalam Angka 2018. Sleman: BPS Sleman.

Brahma, S., Narzary, H., and Basumatary, S., 2013. Wild Edible Fruits of Kokrajhar District of Assam, North-East India. Asian J. Plant Sci. Res., 3(6):95-100.

Dwipa, A.S., dan Priyanti, 2016. Suku Fabaceae di Kampus Universitas Islam Negeri (UIN) Syarif Hidayatullah, Jakarta, Bagian I: Tumbuhan Polong Berperawakan Pohon. Al Kauniyah Jurnal Biologi, 9(1):45-57.

Hoek, F., Ghofir, A., dan Arfah, A., 2014. Estimasi Indeks Keragaman Ikan Karang di Daerah Perlindungan Laut (DPL) Kabupaten Raja Ampat-Papua Barat. Jurnal Airaha, 3(1):1.

Insafitri, 2010. Keanekaragaman, Kemerataan, dan Dominansi Bivalvia di Area Buangan Lumpur Lapindo Muara Sungai Porong. Jurnal Kelautan, 3(1):54-59.
Navia, Z.I., Suwardi, A.B., dan Saputri, A., 2017. Penelusuran Ragam Jenis Tanaman Buah Pekarangan Sebagai Sumber Nutrisi Bagi Masyarakat di kota Langsa, Aceh. SEMNAS BIOETI KE-4 \& KONGRES PTTI KE-12.

Peraturan Daerah Kabupaten Sleman Nomor 3 Tahun 2017 tentang Perubahan atas Peraturan Daerah Nomor 9 Tahun 2016 tentang Rencana Pembangunan Jangka Menengah Daerah Tahun 2015-2021.

Peraturan Menteri Pekerjaan Umum No 05 Tahun 2008 tentang Pedoman Penyediaan dan Pemanfaatan Ruang Terbuka Hijau di Kawasan Perkotaan.

Priyanti dan Fauziah, R., 2016. Analisa Tanaman Buah di Kecamatan Ciputat Kota Tangerang Selatan, Provinsi Banten. Jurnal Riau Biologia, 1(2):140-148.

Sarwadi, A. dan Irwan, S.N.R., 2018. Pemanfaatan Area Pekarangan Sebagai Lanskap Produktif di Permukiman Perkotaan. Arsitektur, 16(1):40-48.

Suhartini, 2015. Model Kearifan Lingkungan Masyarakat dalam Mengkonservasi Keanekaragaman Hayati di Lahan Pekarangan Kabupaten Sleman. Disertasi Ilmu Lingkungan: UGM Yogyakarta.

Waugh, D., 2014. Geography an Integrated Approach, Fourth Edition. Oxford: Oxford University Press. 